\title{
A VIRUS IN RHEUMATISM
}

\author{
BY G. HARDY EAGLES, \\ The Lister Institute, London
}

A VARIETY of organisms have from time to time been believed to have ætiological significance in rheumatism. Chief amongst these are streptococci and, in acute rheumatic fever, the hæmolytic streptococcus. It is well recognised that infection with this organism is a common occurrence in this disease, and although an enormous literature points very strongly to its importance in the clinical course and in precipitating relapses, streptococci, in common with all other agents to which causal significance has attached, have not been proven to be directly responsible. This rests upon the fact that the true picture of rheumatism has never been produced experimentally. The evidence, strong though it may be, is still purely circumstantial. There has longo been a growing tendency to consider the possibility of a virusa being implicated either solely or in conjunction with organisms such as streptococci, and attempts have been made in the past to show that this is the case. It was not, however, until 1935, when Schlesinger, Signy and Amies published the results of their researches on the ætiology of acute rheumatism, that any support was given to this interesting hypothesis. These authors used the high-speed centrifuge to obtain from rheumatic exudates deposits of particles, morphologically similar to elementary bodies from known viruses, from which suspensions were prepared. When these and sera from patients who were suffering from and resisting an acute rheumatic infection were set up in hangingdrop preparations, agglutination of the particles was observed microscopically. Suspensions of particles from non-rheumatic sources remained unagglutinated by these sera set up in the same way. It was therefore suggested that the particles thus isolated from rheumatic exudates were true virus bodies and represented the actual infective agent of the disease. Adequate controls were used throughout. From analogy with the behaviour of known virus suspensions, such as vaccinia, in the presence of 
immune serum, the evidence from the standpoint of agglutination was, at least, highly suggestive. There remained two main avenues of inquiry to be explored. First, to apply similar technique to other members of the rheumatic group of diseases to discover, if possible, a common factor; and second, and most important, to ascertain if these particles could be shown to possess infectivity. It must be clearly understood that morphological and serological data are not sufficient proof that these particles are true virus bodies, or that they are the causative agent of the disease from which they were isolated.

Eagles, Evans, Fisher and Keith (1937) have repeated the work of Schlesinger and his co-workers, and at the same time extended their observations to include rheumatoid arthritis and acute chorea. By methods of high-speed and differential centrifugation they obtained particle suspensions from pericardial, pleural and joint fluids and fibrin in "bread and butter" pericarditis from cases of acute rheumatic fever, from joint fluids, joint washings, and synovial membrane in rheumatoid arthritis, and from cerebro-spinal fluid in a fatal case of chorea with carditis and nodules. These suspensions in stained smear preparations and under dark-ground illumination were indistinguishable from known virus elementary bodies. They also bore a close resemblance to suspensions prepared from exudates from non-rheumatic sources. Suspensions of particles may be prepared from any infective pathological exudate and cannot be distinguished on morphology alone from rheumatic suspensions.

Since these particles are not confined to rheumatic infection, agglutination reactions were used to test their relation to rheumatism. The technique used was identical with that employed by Schlesinger and his co-workers. Equal parts of suspension and test serum in suitable dilutions were mixed in hanging-drop preparations, incubated at room temperature and examined on successive days by low power of the microscope. Positive agglutination was shown by the presence of small, highly refractile clumps appearing after twenty-four to forty-eight hours. In negative tests the suspension settled out on the bottom of the drop in an even ground-glass-like deposit. Sera were selected to include patients suffering from rheumatism of various typesacute rheumatic fever, acute, subacute and chronic rheumatoid arthritis, chorea with and without carditis, and an occasional 
case of Still's disease. The rheumatic group included the disease in all stages, although the majority were in the active stage with evidence of widespread infection, such as carditis, pericarditis, subcutaneous nodules, pyrexia and increased erythrocyte sedimentation rate. A control group of sera included cases of widely differing clinical diseases, but excluding those with a history of rheumatism. A number were selected on the basis of high erythrocyte sedimentation rate, of a very strongly positive Wassermann complement fixation reaction and of pyrexial states of non-rheumatic origin.

Cross-agglutination tests were also made for the presence of an antigenic factor common to the members of the group of rheumatic diseases.

Table I.-Suspensions for Agglutination

\begin{tabular}{|c|c|c|c|c|c|}
\hline \multirow{2}{*}{ Specimen. } & \multirow{2}{*}{$\begin{array}{l}\text { Number } \\
\text { of Sus- } \\
\text { pensions. }\end{array}$} & \multirow{2}{*}{ Disease. } & \multicolumn{3}{|c|}{$\begin{array}{l}\text { Agglutination with Serum } \\
\text { from : }\end{array}$} \\
\hline & & & $\begin{array}{c}\text { Rheumatic } \\
\text { Fever. }\end{array}$ & $\begin{array}{c}\text { Rheumatoid } \\
\text { Arthritis. }\end{array}$ & Chorea. \\
\hline $\begin{array}{l}\text { Pericardial } \\
\text { fluid }\end{array}$ & 7 & Fatal rhou- & $7+$ & $3+$ & $3+$ \\
\hline $\begin{array}{l}\text { Fibrin from } \\
\text { pericarditis }\end{array}$ & 2 & Ditto & $2+$ & $\underset{\text { tested }}{\text { Not }}$ & $\begin{array}{l}\text { Not } \\
\text { tested. }\end{array}$ \\
\hline Ploural fluid & 3 & $\begin{array}{l}\text { Rheumatic } \\
\text { fever }\end{array}$ & $3+$ & Ditto & $1+$ \\
\hline Joint fluid $\quad$. & 3 & $\begin{array}{l}\text { Rheumatoid } \\
\text { arthritis }\end{array}$ & $2+$ & $3+$ & $\begin{array}{l}\text { Not } \\
\text { tested. }\end{array}$ \\
\hline Joint washing & 1 & Ditto & 0 & $\underset{\text { Nested }}{\text { Not }}$ & Ditto. \\
\hline $\begin{array}{c}\text { Synovial mem- } \\
\text { brane }\end{array}$ & 1 & Ditto & $\begin{array}{l}\text { Not } \\
\text { tested }\end{array}$ & $1+$ & Ditto. \\
\hline $\begin{array}{l}\text { Cerebro-spinal } \\
\text { fluid }\end{array}$ & 1 & $\begin{array}{l}\text { Chorea with } \\
\text { carditis and } \\
\text { nodules }\end{array}$ & $1+$ & $\underset{\text { tested }}{\text { Not }}$ & $1+$ \\
\hline \multirow{3}{*}{$\begin{array}{l}\text { Controls. } \\
\text { Peri c a r d i a l } \\
\text { fluid }\end{array}$} & \multirow{3}{*}{3} & \multirow{5}{*}{$\begin{array}{c}\text { (1) Cor bovi- } \\
\text { num } \\
\text { (2) Bacterial } \\
\text { endocarditis } \\
\text { (3) Heart } \\
\text { failure } \\
\text { Tubercular } \\
\text { pleurisy } \\
\text { Lapine }\end{array}$} & & & \\
\hline & & & $\begin{array}{l}0 \\
0\end{array}$ & $\begin{array}{l}\text { Not } \\
\text { tested } \\
\text { Ditto }\end{array}$ & $\begin{array}{c}\text { Not } \\
\text { tested. } \\
\text { Ditto. }\end{array}$ \\
\hline & & & $\mathbf{0}$ & Ditto & Ditto. \\
\hline Ploural fluid & 1 & & 0 & Ditto & Ditto. \\
\hline Vaccinia $\quad \ldots$ & 1 & & 0 & Ditto & Ditto. \\
\hline
\end{tabular}


Table I. presents schematically the suspensions tested, their source and their behaviour in agglutination tests with sera from cases of rheumatic fever, rheumatoid arthritis and chorea. The control suspensions included vaccinia virus, because the appearance and serological reactions of this virus, having been the subject of widespread research, are well known. These control suspensions were tested with rheumatic fever sera only.

The results of agglutination tests made with these suspensions and sera from patients may be summarised as follows: Of 263 specimens of serum from cases of active rheumatic fever, 123 agglutinated suspensions obtained from acute rheumatic fever. Of nine sera from inactive rheumatic fever, four reacted positively. Of eight cases of chorea, five reacted positively. Of twenty-one cases of rheumatoid arthritis, seven reacted positively. Twenty-one control sera gave no agglutination with these acute rheumatic fever suspensions. When a proportion of these sera was tested with suspensions from rheumatoid arthritis and a fatal case of chorea, the distribution of positives and negatives was very similar to that observed with suspensions from rheumatic fever.

Particle suspensions from non-rheumatic sources were not agglutinated by the test sera.

Cross-agglutination, therefore, occurred with sufficient regularity to point to an inter-relationship between acute rheumatic fever, rheumatoid arthritis and chorea. This is not a new conception. Dawson and Tyson (1936) concluded that rheumatic fever and rheumatoid arthritis were intimately related on the grounds of familial relationship, geographic distribution, initiating factors, seasonal incidence, age incidence, clinical manifestations in different age periods, pathological similarity of the subcutaneous nodules and streptococcal immunological findings. Fisher (1937), on histological evidence, also concluded that the two diseases were intimately related. Collins (1937), however, in a histological study of the subcutaneous nodules in both diseases, found insufficient evidence of resemblance to postulate either a close relationship or a common ætiology.

An attempt was made to assess the importance as judged by agglutination of different clinical factors in acute rheumatic fever.

The following table shows the results of agglutination tests 
with suspensions from rheumatic fever, rheumatoid arthritis, and chorea with sera from cases presenting well-marked phases in the course of rheumatic disease:

TABLE II.

\begin{tabular}{|c|c|c|c|c|c|c|c|}
\hline \multirow{3}{*}{ Sera Type of Case. } & \multirow{3}{*}{$\begin{array}{l}\text { Number } \\
\text { of Cases. }\end{array}$} & \multicolumn{6}{|c|}{$\begin{array}{c}\text { Agglutination of Suspensions } \\
\text { from : }\end{array}$} \\
\hline & & \multicolumn{2}{|c|}{$\begin{array}{l}\text { Rheumatic } \\
\text { Fever. }\end{array}$} & \multicolumn{2}{|c|}{$\begin{array}{c}\text { Rheumatoid } \\
\text { Arthritis. }\end{array}$} & \multicolumn{2}{|c|}{$\begin{array}{c}\text { Chorea } \\
\text { (Cerebro- } \\
\text { spinal } \\
\text { fluid). }\end{array}$} \\
\hline & & + & O & + & $\mathrm{O}$ & + & o \\
\hline $\begin{array}{l}\text { Active rheumatic fever } \\
\text { without carditis or } \\
\text { chorea }\end{array}$ & 4 & 2 & 2 & 1 & 2 & - & - \\
\hline $\begin{array}{l}\text { Active rheumatic fever } \\
\text { with carditis }\end{array}$ & 67 & 31 & 36 & 12 & 7 & 5 & 2 \\
\hline 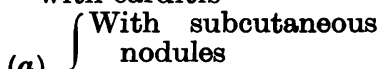 & 21 & 13 & 8 & 5 & 2 & 2 & - \\
\hline (a) $\left\{\begin{array}{l}\text { Without subcutan- } \\
\text { eous nodules }\end{array}\right.$ & 44 & 17 & 27 & 7 & 5 & 3 & 2 \\
\hline $\begin{cases}\text { First attack } & \ldots \\
\text { Recurrence } & \ldots\end{cases}$ & $\begin{array}{l}28 \\
36\end{array}$ & $\begin{array}{l}17 \\
13\end{array}$ & $\begin{array}{l}11 \\
23\end{array}$ & $\begin{array}{l}8 \\
4\end{array}$ & 1 & $\mathbf{3}$ & $\overline{2}$ \\
\hline$\left\{\begin{array}{l}\text { Recent throat in- } \\
\text { fection }\end{array}\right.$ & 17 & 10 & 7 & 3 & 2 & 2 & 一 \\
\hline (c) $\left\{\begin{array}{c}\text { No known recent } \\
\text { throat infection }\end{array}\right.$ & 46 & 20 & 26 & 9 & 6 & 3 & 2 \\
\hline $\begin{array}{l}\text { Inactive rheumatic fever } \\
\text { Chorea alone }\end{array}$ & $\begin{array}{l}9 \\
8\end{array}$ & 4 & 5 & 2 & 4 & 2 & 3 \\
\hline $\begin{array}{ll}\text { Chorea alone } & \ldots \\
\text { Rheumatoid arthritis } & \ldots\end{array}$ & $\begin{array}{r}8 \\
26\end{array}$ & $\begin{array}{l}5 \\
7\end{array}$ & $\begin{array}{r}3 \\
14\end{array}$ & $\begin{array}{l}1 \\
6\end{array}$ & $\begin{array}{r}1 \\
15\end{array}$ & 1 & E \\
\hline $\begin{array}{lll}\text { Control sera } & \ldots & \ldots\end{array}$ & 21 & 0 & 21 & 0 & 1 & 0 & 1 \\
\hline
\end{tabular}

Positive agglutination was not confined to sera from active cases. It was found difficult to assess the relationship of carditis to agglutination, since it is an almost constant manifestation of the acute type. The presence of nodules also did not run parallel to agglutination, though it was thought that a higher proportion of positive reactions occurred when they were present. A suggestively higher proportion of positives occurred during a first attack as compared with those suffering recurrence. In the control group of sera it was shown that pyrexial states, increased erythrocyte sedimentation rate or positive Wassermann 
reaction were not responsible for the agglutination of the suspensions.

In collaboration with Dr. W. H. Bradley, the Department of Medicine, University of Cambridge, a further and more prolonged study has been made in an attempt to determine, if possible, the precise relationship of the phenomenon of agglutination of the virus-like bodies from rheumatic exudates by sera of rheumatic cases to the stages of rheumatic infection. This has necessitated frequent tests with each patient's serum, since the clinical course included all the episodes common to the disease, including streptococcal infection.

The study comprised cases of acute rheumatic fever, rheumatoid arthritis, infectious arthritis, chorea, and pyrexial states of unknown origin accompanied by joint manifestations. Agglutination occurred in quite a striking manner in the acute rheumatic fever and acute rheumatoid arthritis cases. Many of these cases, however, gave negative results. Agglutination was also obtained from sera from a number of cases of arthropathies unrelated to true rheumatic disease, so that it cannot be maintained that the reaction is confined to rheumatic fever, rheumatoid arthritis and chorea. It was, however, sufficiently striking in these diseases to uphold earlier observations that the phenomenon is a very real one, although its true nature is not at present understood. It is not yet possible in our series to assess accurately the relation of the agglutination test to streptococcal infection or other phases of the rheumatic cycle.

Concurrently with serological tests infection experiments were carried out. Monkeys were used because of their generic relationship to man, in whom rheumatism is a naturally occurring disease. Suspensions from acute rheumatic fever, rheumatoid arthritis and chorea were injected intrapericardially, intraperitoneally, intracerebrally, intravenously, intramuscularly, intratracheally, into the joint cavities and into the nasal mucosa. Suspensions were used with as little delay as possible, and were given alone and in combination with hæmolytic streptococci and scarlet fever toxin. In some instances repeated doses were given by various routes. The suspensions were bacteriologically sterile. Constant clinical supervision was given to test animals, including frequent electrocardiograms and erythrocyte sedimentation rates. In a series of thirty-five monkeys only certain animals call for comment. In two instances the clinical behaviour 
suggested grave cardiac damage, as evidenced by dyspnœa, pallor and cyanosis, gallop rhythm, and collapse. Electrocardiographic tracings showed a P.R. interval of 0.09 second, as compared with 0.08 second, which appears to be normal for the rhesus monkey. In addition, " $T$ " waves were inverted in leads I. and II. In one case suspension alone had been inoculated, and in the second, suspension plus toxin. At post-mortem neither endocarditis nor pericarditis was present, nor were there signs of such at any time during the illness. The valves were apparently normal. Pathological sections revealed a widespread and moderately severe myocarditis. Collections of inflammatory cells were common near small vessels, and bore a superficial resemblance to Aschoff nodes. But the typical multinucleated cells were never found. The picture called to mind the lesions in experimental scurvy described by Taylor (1937), though they were much less severe. The pathological picture was, indeed, not sufficiently severe to account for the grave clinical symptoms, and up to the present an adequate explanation has not been found. It has not so far been encountered in a very considerable number of laboratory monkeys under observation in other studies of this Institute. Myocarditis and myocardial degeneration occurred in other monkeys in the series in varying but mild degrees. In one instance it occurred when toxin alone was injected, and thereby prevents any conclusion being drawn that it is a result of the action of suspension alone or in combination with toxin, especially in view of the fact that, in a series of nine control monkeys, some degree of myocarditis with increased cellularity was found in three instances. It is possible that myocarditis of a chronic type is due to some common infection in laboratory monkeys.

In our animals slight œdema in one or more joints with some tenderness has occurred, but was of mild degree. Subcutaneous nodules have never been observed. Some increase in erythrocyte sedimentation rate has been observed in one instance, but it must be remembered that increased rate is not confined to rheumatic infection.

The average P.R. interval in the electrocardiogram of the rhesus monkey appears to be about 0.08 second when the heart rate is approximately 240. An interval exceeding 0.08 second was found when suspension alone was injected with toxin alone, and when the two were combined. The P.R. interval in these 
instances never exceeded 0.09 second. This may be without significance, and may be within normal limits for the monkey. Inversion of " $T$ " waves in leads $I$. and II. and flat $T_{2}$ in lead I. also occurred, but these also did not appear to be associated only with injection of toxin. In view of the severity of the clinical condition in the two monkeys and the lack of typical pathological findings, it would be unwarranted to attach undue significance to these abnormalities in electrocardiographs, since these in the human subject are not confined to rheumatic carditis.

In view of serological findings and our failure to reproduce the picture of rheumatic disease in animals, it may be well to consider the attitude which should be taken in future work. The Aschoff node and non-bacterial verrucous endocarditis and pericarditis are confined to acute rheumatism in the human subject. Gross, Loewe and Eliasoph (1929) adopted these as the criterion of the experimental disease for their work. It may be necessary to modify this attitude, for experience may show that these conditions cannot be reproduced in any animal other than man. Instances of human diseases, whose exact counterpart has not been reproduced in experimental animals, may readily be found (scarlet fever, chicken-pox, herpes zoster).

Since definite infective properties have not been shown for these virus-like bodies, we are confronted with the necessity of explaining the serological findings. There are two main views to be taken. First, they may be virus particles, but cannot be proven so in the absence of a suitable experimental animal. Second, the reaction may have some definite specific relationship in the disease, but the actual particles have no ætiological significance. Proteus X19 in typhus, the precipitinogen described by Hughes (1933) in yellow fever, which was shown by infectivity tests not to be the virus itself, though the reaction with immune serum was specific, and the work on a fraction extracted from the pneumococcus by Tillet and Francis (1930), which gave a precipitin reaction with the sera of patients in a pyrexial state, may be quoted as examples.

It now seems reasonable to assume that rheumatic disease is a complex one in which many factors which are not understood may play important parts. No one seriously doubts the importance of streptococci in rheumatism, and it has even been suggested that these particles may be a product of streptococcal 
infection. Against this view is the fact that sera from streptococcal infection in the absence of a rheumatic history have not given positive agglutinations. Nor must the possibility of the rôle of states of metabolic imbalance be forgotten.

\section{REFERENCES}

Amies, C. R. (1933): Lancet, i. 1015.

Amies, C. R. (1934): Brit. Journ. Exp. Path., xv. 314.

Collins, D. H. (1937): Journ. Path. Bact., xlv. 97.

Dawson, M. H., and Tyson, T. L. (1936): Journ. Lab. Clin. Med., xxi. 575. Eagles, G. H., Evans, P. R., Fisher, A. G. Timbrell, and Keith, J. D. (1937): Lancet, ii. 421.

Fisher, A. G. Timbrell (1937): Lancet, i. 1162.

Gross, L., Loewe, L., ANd Eliasoph, B. (1929): Journ. Exp. Med., 1. 41. HuaHes, T. P. (1933): Journ. Immunol., xxv. 275.

Schlesinger, B., Signy, A. G., AND Amies, C. R. (1935): Lancet, i. 1145. Tillet, W. S., and Francis, T., JR. (1930): Journ. Exp. Med., lii. 561. 